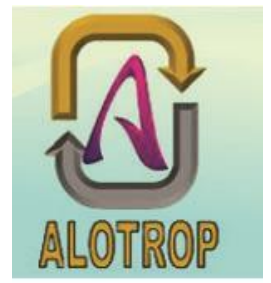

\section{POTENSI AKTIVITAS ANTIOKSIDAN METABOLIT SEKUNDER DARI BAKTERI ENDOFIT PADA DAUN Moringa oleifera $\mathbf{L}$}

Susi Juni Yati*1, Sumpono ${ }^{2}$, I Nyoman Candra ${ }^{3}$

1,2,3 Program Studi Pendidikan Kimia Jurusan PMIPA FKIP

Universitas Bengkulu

e-mail : susijuniyati@gmail.com

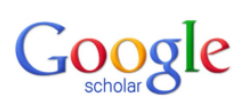

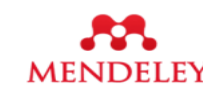

Yö̀ PKPINDEX

SBASE

\title{
Abstract
}

[POTENTIAL ANTIOXIDANT ACTIVITY OF SECONDARY METABOLITES FROM ENDOPHYTE BACTERIA ON Moringa oleifera L LEAF] This research aims to know the similarities between secondary compound metabolites produced by endophyte bacterial on host leaves and from Moringa oleifera L (kelor) leaves as well as determine the magnitude of antioxidant activity compounds of secondary metabolites produced by bacterial endophyte. Based on the results of the test compound is secondary metabolite in both samples, for secondary metabolite compounds in the extract of the leaves of M. oleifera L. contains identified steroid compounds, flavonoids, saponins, tannins and phenolic compounds, while for metabolites secondary bacterial endophyte undetectable on the existence of any secondary metabolite compounds.For testing of antioxidants on endophyte bacterial extracts of leaves of M. oleifera $\mathrm{L}$ is done using the DPPH method, performed on variations of the concentration of 200, 400, 600, 800, and $1000 \mathrm{ppm}$ with Ascorbic acid as a comparison. The results of the test get an $\mathrm{IC}_{50}$ of M. oleifera L leaf extract at $243.67 \mathrm{ppm}$, and supernatan extract from endophyte bacterial at $492 \mathrm{ppm}$. The $\mathrm{IC}_{50}$ values showed antioxidant activity in secondary metabolite compounds derived from extracts of the leaves of M. oleifera $\mathrm{L}$ which has an extreme antioxidant category. The amount of antioxidant activity for secondary metabolite compound extracts of bacterial endophyte on leaves of $M$. oleifera $\mathrm{L}$ category is feeble, and to extract the supernatan activity is weak compared to the value of the antioxidant activity of Ascorbic acid.

Keywords: Moringa oleifera L (kelor), endophyte bacterial, antioxidant, DPPH.

\section{Abstrak}

Penelitian ini bertujuan untuk mengetahui kesamaan antara senyawa metabolit sekunder yang dihasilkan oleh bakteri endofit pada daun Moringa oleifera L (kelor) dengan senyawa metabolit sekunder tanaman inang, serta menentukan besarnya aktivitas antioksidan dari senyawa metabolit sekunder yang dihasilkan oleh bakteri endofit tersebut. Berdasarkan hasil uji senyawa metabolit sekunder pada kedua sampel, untuk senyawa metabolit sekunder pada ekstrak daun $M$. oleifera L teridentifikasi mengandung senyawa-senyawa steroid, flavonoid, saponin, tanin dan fenol, sedangkan untuk senyawa metabolit sekunder pada bakteri endofit tidak terdeteksi keberadaan dari senyawa metabolit sekunder apapun. Untuk pengujian antioksidan pada ekstrak bakteri endofit daun $M$. oleifera L dilakukan menggunakan metode DPPH, yang dilakukan pada variasi konsentrasi 200, 400, 600, 800, dan 1000 ppm dengan asam Askorbat sebagai pembanding. Hasil uji diperoleh nilai $\mathrm{IC}_{50}$ dari ekstrak daun $M$. oleifera $\mathrm{L}$ sebesar 243,67 ppm, dan ekstrak supernatan dari bakteri endofit sebesar 492 ppm. Nilai IC 50 tersebut menunjukkan aktivitas antioksidan yang terkandung di dalam senyawa metabolit sekunder yang berasal dari ekstrak daun $M$. oleifera L yang memiliki kategori antioksidan sangat kuat. Nilai aktivitas antioksidan untuk ekstrak senyawa metabolit sekunder dari bakteri endofit pada daun $M$. oleifera L adalah berkategori sangat lemah, dan untuk ekstrak supernatannya memiliki aktivitas yang lemah dibandingkan nilai aktivitas antioksidan dari asam Askorbat.

Kata kunci : Moringa oleifera L (kelor), bakteri endofit, DPPH, antioksidan.

\section{PENDAHULUAN}

Potensi tanaman obat merupakan sumber daya hayati yang sangat besar untuk dikembangkan sebagai bahan baku dari obat herbal yang berbasis pada tanaman obat [1], dimana ada ribuan spesies tumbuhan yang telah dimanfaatkan sebagai bahan baku obat. [2] Khasiat dari tanaman obat adalah karena adanya kandungan metabolit sekunder dengan berbagai struktur molekul dan tingkat aktivitas biologissehingga dapat mengurangi dan mengobati berbagai penyakit [3]. Karena itu pemanfaatan dari suatu tanaman obat terhadap suatu penyakit adalah karena adannya kandungan senyawa metabolit sekunder yang dimilikinya [4], contohnya adalah tanaman Moringa oleifera L (kelor) [5]. Hasil uji fitokimia terhadap daun $M$. oleifera L diketahui mengandung berbagai 
senyawa metabolit sekunder seperti tannin, steroid, triterpenoid, flavonoid, saponin, antarquinon, dan alkaloid [6]. Hasil berbagai penelitian menunjukkan bahwa senyawa-senyawa metabolit sekunder seperti alkaloid, tannin, steroid, terpenoid, flavonoid, saponin, quinondan alkaloid semuanya merupakan senyawa-senyawa yang mampu bertindak sebagai antioksidan dan memiliki potensi sebagai obat [7]. Hasil penelitian terdahulu terhadap daun $M$. oleifera Lterbukti bahwa memiliki kekuatan antioksidan 7 kali lebih banyak bila dibandingkan dengan vitamin C.[8], sehingga salah satu hal paling menonjol dari pemanfaatan daun $M$. oleifera $\mathrm{L}$ yaitu bila digunakan sebagai antioksidan [9]. Efektivitas antioksidan pada daun $M$. oleifera L telah terbukti bekerja sangat baik sehingga banyak dimanfaatkan sebagai obat herbal tradisional. [10], bahkan saat ini sudah diproduksi secara besar-besaran dalam skala komersial [11].Untuk menghasilkan obat herbal secara komersial akan dibutuhkan sumber bahan baku yang besar secara kontinu [12], sehingga untuk itu dalam menangani ketersediaan bahan baku yang konstan diperlukan pengembangan bioteknologi, salah satunya adalah dengan mengembangan mikroba endofit. [13] yang ada dijaringan tanaman inangnya [14], baik berupa jamur dan bakteri yang hidup dalam jaringan tanaman pada periode tertentu dengan membentuk koloni dalam jaringan tanaman tanpa membahayakan inangnya [15] dan terutama kan dapat menghasilkan senyawa bioaktif yang memiliki karakternya hampir sama dengan tumbuhan inangnya [16]. Penelitian isolatif terhadap bakteri endofit pada berbagai tanaman sudah banyak dilaporkan, antara lain dari spons karang [17], kunyit [18], ketepeng cina [19], yang menyatakan bahwa kemampuan bakteri endofit yang dihasilkan sama dengan kemampuan inangnya. [20]. Upaya untuk pemanfaatan kandungan senyawa metabolit sekunder daun $M$. oleifera L merupakan latarbelakang dari upaya untuk melakukan isolasi bakteri endofit serta potensi antioksidan yang sama dengan inangnya, [21] serta memperkuat hasil penelitian sebelumnya tentang aktivitas antioksidan bakteri endofit [22], yang menggunakan metode DPPH (1,1-diphenyl-2-picrylhydrazyl). Metode uji DPPH digunakan karena sederhana, cepat, dan mudah untuk skrining aktivitas penangkap radikal beberapa senyawa, selain itu akurat dan praktis [23]. Penelitian ini bertujuan untuk menguji kesamaan senyawa metabolit sekunder bakteri endofit dari daun kelor dan inangnya serta menguji aktivitas antioksidan senyawa metabolit yang dihasilkan oleh bakteri endofit dari daun kelor menggunakan metode DPPH..

\section{METODE PENELITIAN}

Untuk membuat ekstrak daun Moringa oleifera L (kelor), sampel daun M.oleifera L dibersihkan lalu diangin-anginkan selama 14 hari untuk menghilangkan kadar airnya . Timbang sebanyak 200 g sampel daun kering, dan dihaluskan sehingga menjadi serbuk, dilanjutkan dengan proses maserasi menggunakan pelarut etil asetat sebanyak 2L selama 3 hari. Setelah 3 hari campuran disaring dengan kertas saring, dan hasilnya disebut filtrat I. Serbuk yang terpisahkan selanjutnya diremaserasi kembali dengan $1 \mathrm{~L}$ pelarut yang sama selama 2 hari, dan kemudian disaring lagi dengan kertas saring untuk memperoleh filtrat II.Filtrat I dan II selanjutnya digabungkan lalu dipekatkan menggunakan vaccum rotary evaporator pada suhu $40{ }^{\circ} \mathrm{C}$ untuk memperoleh ekstrak kental, yang akan digunakan untuk uji fitokimia dan uji antioksidan.

Untuk proses isolasi bakteri endofit pada daun, ambil sebanyak 4 helai daun $M$. oleifera $\mathrm{L}$ yang masih segar dicuci di bawah air mengalir selama 10 menit, dan kemudian disterilisasi permukaannya di dalam Laminar Air Flow Cabinet (LAFC), dan selanjutnya direndam de-ngan larutan alkohol $70 \%$ selama 1 menit, sambil dikocok pelan, selanjutnya dipindahkan ke dalam larutan hipoklorit $(\mathrm{NaOCl}) 5,25 \%$ selama 5 menit, dilanjutkan dengan perendaman kembali daun ke dalam larutan alkohol $70 \%$ selama 30 detik, kemudian dibilas dengan aquades steril selama 1 menit dan perlakuan diulang sebanyak 2 kali. Daun yang telah steril tersebut selanjutnya dikeringkan di atas kertas saring steril. Selanjutnya daun M.oleifera $\mathrm{L}$ yang telah dibersihkan ditanam ke dalam media MS. Penanaman dilakukan dengan menggunakan pinset steril. Penanaman daun dalam posisi horizontal. Kemudian diinkubasikan selama 2-3 hari pada suhu $37{ }^{\circ} \mathrm{C}$. Setelah inkubasi, akan tampak pertumbuhan bakteri endofit disekitar daun $M$. oleifera L. Suspensi bakteri sebanyak 0,1\% ditumbuhkan dalam media NB sebanyak $10 \mathrm{~mL}$ lalu digojok dengan kecepatan 170 rpm, selama 72 jam pada suhu $37{ }^{\circ} \mathrm{C}$. Hasil fermentasi disentri-fugasi pada kecepatan 3000 rpm selama 20 menit untuk memisahkan supernatan dan biomassa.Supernatan yang diperoleh digunakan sebagai uji aktivitas 
antioksidan dan uji fitokimia. Supernatan yang diperoleh kemudian diekstraksi dengan etil asetat dengan perbandingan $(1 / 2: \mathrm{v} / \mathrm{v})$ dengan menggunakan corong pisah dan didiamkan selama 20 menit. Lapisan atas (Fase etil asetat) dituang ke dalam erlenmeyer sedangkan residu cairan media (lapisan bawah) diikutkan ke ekstraksi berikutnya. Fase etil asetat selanjutnya dipekatkan dengan menggunakan rotavapor pada suhu $35^{\circ} \mathrm{C}$ sehingga diperoleh ekstrak kental, untuk digunakan pada uji fitokimia dan uji antioksidan.

Untuk uji alkaloid, sebanyak $1 \mathrm{~mL}$ ekstrak etil asetat daun kelor ditambah $10 \mathrm{~mL}$ kloroform dan 3 tetes $\mathrm{NH}_{4} \mathrm{OH}$ dalam tabung reaksi. Ekstrak kloroform dipisah dan diberi 10 tetes $\mathrm{H}_{2} \mathrm{SO}_{4} 2 \mathrm{M}$, kemudian dikocok secara teratur dan dibiarkan beberapa saat hingga terbentuk dua lapisan. Lapisan asam (atas) yang diperoleh kemudian dipisah ke dalam 2 tabung reaksi kemudian tabung 1 ditetesi pereaksi Mayer dan tabung 2 ditetesi dengan pereaksi wagner. Terdapatnya alkaloid ditandai dengan terbentuknya endapan putih oleh pereaksi mayer dan endapan coklat oleh pereaksi wagner. Untuk uji steroid dan triterpenoid, . sebanyak $1 \mathrm{~mL}$ ekstrak etil asetat daun kelor ditambahkan dengan $10 \mathrm{~mL}$ eter selama 10 menit. Lapisan eter dipisah lalu ditambah 3 tetes pereaksi Lieberman-Burchard (3 tetes anhidridat asetat dan 3 tetes kloroform) dan 1 tetes $\mathrm{H}_{2} \mathrm{SO}_{4}$ Pekat. Terbentuknya warna merah atau ungu menunjukkan kandungan triterpenoid sedangkan warna hijau atau biru menunjukkan kandungan steroid. Untuk uji alkaloid sebanyak 2 $\mathrm{mL}$ ekstrak etil asetat daun kelor dimasukkan ke dalam air mendidih selama 5 menit. Ditambah serbuk $\mathrm{Mg}, 1 \mathrm{~mL} \mathrm{HCl}$ pekat dan 20 tetes alkohol lalu dikocok kuat. Terbentuknya warna merah, kuning atau jingga menunjukkan terdapatnya senyawa flavonoid. Untuk uji saponin sebanyak 2 ml ekstrak etil asetat daun Kelor dikocok selama 15 detik. Timbulnya busa hingga selang waktu 10 menit menunjukkan adanya saponin . Untuk uji tanin sampel sebanyak $1 \mathrm{~mL}$ ditambahkan sebanyak $\mathrm{NaCl} 10 \%$ kemudian disaring lalu filtrat ditambah larutan gelatin $1 \%$ dan larutan $\mathrm{NaCl}$ $10 \%$. Bila terdapat endapan pada sampel menunjukkan adanya tanin. Untuk uji fenol Sebanyak 1 mL ekstrak etil asetat daun kelor ditambah 10 tetes $\mathrm{FeCl}_{3}$. Terbentuknya warna biru tua atau hitam kehijauan menunjukkan terdapatnya fenol. Untuk uji aktivitas antioksidan dengan metode DPPH, masing-masing larutan uji yang telah dibuat

Yati, S.J, Sumpono, I Nyoman Candra diambill sebanyak $1 \mathrm{~mL}$ dan dimasukkan ke dalam tabung reaksi, kemudian ditambahkan $2 \mathrm{~mL}$ metanol dan $1 \mathrm{~mL}$ larutan DPPH $100 \mathrm{ppm}$. Dikocok hingga homogen dan didiamkan selama 30 menit. Selanjutnya diukur serapannya pada panjang gelombang maksimum yang telah diperoleh yaitu $517 \mathrm{~nm}$ dengan menggunakan spektrofotometer Uv-Vis.Untuk mennentukan nilai persentase inhibisi $\left(\mathrm{IC}_{50}\right)$ terhadap radikal DPPH dari masingmasing konsentrasi larutan sampel dapat dihitung dengan rumus :

\section{$\%$ Inhibisi $=\underline{(\text { Abs. Blanko }- \text { Abs. Sampel })} \times 100 \%$ Absorbansi Blanko}

Nilai persentase inhibisi dari masing-masing konsentrasi, digunakan untuk menentukan persamaan regresi linier $y=a+b x$, dimana $X$ adalah konsentrasi (ppm) dan y adalah besarnya nilai persentase inhibisi (\%) [ 24]

Antioksidan dinyatakan dengan Inhibition Concentration $50 \%\left(\mathrm{IC}_{50}\right)$ yaitu konsentrasi sampel yang dapat merendam radikal DPPH sebesar $50 \%$, yang nilainya didapatkan dari nilai $\mathrm{x}$ pada persamaan regresi dengan mengganti nilai $y$ menjadi 50. [25 ]

\section{HASIL DAN PEMBAHASAN}

Penelitian dilakukan pada Februari-Juni 2017 di Laboratorium IHPT Universitas Bengkulu, Laboratorium Kedokteran Universitas Bengkulu, Laboratorium Basic SainsUniversitas Bengkulu, dan Laboratorium Kimia Universitas Bengkulu.

Pada penelitian ini ekstrak kental daun kelor dan ekstrak supernatan bakteri endofit yang diperoleh kemudian dilakukan uji fitokimia dan uji antioksidan. Pengujian ini dimaksudkan untuk mengetahui kandungan senyawa metabolit sekunder (Tabel 1) dan aktivitas antioksidan.

Tabel 1 : Uji Fitokimia Ekstrak Daun Kelor dan Ekstrak Supernatan Bakteri Endofit

\begin{tabular}{lcc}
\hline \multicolumn{1}{c}{ Sampel } & $\begin{array}{c}\text { Ekstrak Daun } \\
\text { Kelor }\end{array}$ & $\begin{array}{c}\text { Ekstak } \\
\text { Supernatan } \\
\text { Endofit }\end{array}$ \\
\hline Alkaloid & - & - \\
Steroid & + & - \\
Triterpenoid & - & - \\
Flavonoid & + & - \\
Saponin & + & - \\
Tanin & + & - \\
Fenol & + & - \\
\hline
\end{tabular}


Berdasarkan Tabel.1 dapat diamati bahwa hasil yang diperoleh pada ekstrak daun kelor hasil positif ditunjukkan pada uji steroid, flavonoid, saponin, tanin, dan fenol. Sedangkan untuk uji ekstrak supernatan bakteri endofit semua hasil uji menunjukkan hasil negatif. Hasil negatif yang ditunjukkan diduga karena bakteri yang diperoleh tersebut memiliki gen yang mengkode pembentukan senyawa metabolit sekunder, namun tidak terekspesi pada media produksi yang telah digunakan.[26] Gen tersebut akan muncul apabila diinduksi terlebih dahulu. Proses induksi dapat berupa penambahan suatu senyawa prekusor atau penambahan sejumlah tertentu inokulum isolat pada proses fermentasi [27].

Pada uji antioksidan menggunakan metode DPPH dilakukan dengan mengambil konsentrasi ekstrak daun kelor masing-masing 5, 10,25, 50, dan 100 ppm, dan untuk ekstrak supernatan bakteri endofit digunakan konsentrasi 50, 100, 150, 200, dan $250 \mathrm{ppm}$. Sedangkan untuk asam askorbat sebagai larutan pembanding digunakan konsentrasi 3, 6, 9, 12, dan $15 \mathrm{ppm}$. Masing-masing larutaan uji diambil sebanyak $1 \mathrm{~mL}$ dan dimasukkan ke dalam tabung reaksi, kemudian ditambahkan $2 \mathrm{ml}$ metanol p.a dan $1 \mathrm{~mL}$ larutan DPPH $100 \mathrm{ppm}$. Dikocok hingga homogen dan didiamkan selama 30 menit. Selanjutnya diukur seraoannya pada panjang gelombang $517 \mathrm{~nm}$. Berdasarkan hasil pengukuran absorbansi yang diperoleh, kemudian digunakan untuk perhitungan nilai persen inhibisi atau persen perendaman senyawa antioksidan terhadap DPPH. Kemudian dilanjutkan dengan perhitungan $\mathrm{IC}_{50}$. Data nilai absorbansi, persen inhibisi, dan nilai $\mathrm{IC}_{50}$ dapat dilihat pada Tabel 2 . Aktivitas anti oksidan ditunjukkan dengan nilai $\mathrm{IC}_{50}$ yang diperoleh. [28]. Berdasarkan hasil perhitungan nilai $\mathrm{IC}_{50}$ sampel pembanding asam askorbat memiliki nilai sebesar 10,98 ppm, ekstrak daun kelor sebesar 243,67 ppm, dan ekstrak supernatan bakteri endofit 492 ppm. Semakin rendah nilai $\mathrm{IC}_{50}$ maka aktivitas antioksidan semakin baik [29]. Secara spesifik, suatu senyawa dikatakan memiliki aktivitas antioksidan yang sangat kuat bila $\mathrm{IC}_{50}<50 \mathrm{ppm}$, kuat bila $\mathrm{IC}_{50}$ bernilai $50-100$ ppm, sedang bila $\mathrm{IC}_{50}$ bernilai 101-250, dan lemah bila $\mathrm{IC}_{50} 251-500$ ppm [30]

Berdasarkan kriteria nilai aktivitas antioksidan, maka asam askorbat dan ekstrak daun kelor memiliki kategori antioksidan sangat aktif.[31]
Sedangkan ekstrak supernatan bakteri endofit daun kelor memiliki aktivitas yang lemah.[32]. Hal ini dikarenakan kemungkinan senyawa metabolit yang dihasilkan dari supernatan bakteri sedikit, sehingga memiliki aktivitas antioksidan yang lemah [33].

Tabel 2 : Hasil Pengukuran dan Pengujian Antioksidan

\begin{tabular}{llll}
\hline Sampel & Konsentrasi & Absorbansi & $\mathrm{IC}_{50}$ \\
\hline Asam & $3 \mathrm{ppm}$ & 0,568 & \\
Askorbat & $6 \mathrm{ppm}$ & 0,411 & \\
& $9 \mathrm{ppm}$ & 0,282 & 2,74 \\
& $12 \mathrm{ppm}$ & 0,177 & $\mathrm{ppm}$ \\
& $15 \mathrm{ppm}$ & 0,053 & \\
Ekstrak & $5 \mathrm{ppm}$ & 0,701 & \\
Daun Kelor & $10 \mathrm{ppm}$ & 0,679 & \\
& $25 \mathrm{ppm}$ & 0,669 & 10,74 \\
& $50 \mathrm{ppm}$ & 0,629 & $\mathrm{ppm}$ \\
& $100 \mathrm{ppm}$ & 0,580 & \\
Ekstrak & $200 \mathrm{ppm}$ & 0,597 & \\
Supernatan & $400 \mathrm{ppm}$ & 0,543 & \\
Endofit & $600 \mathrm{ppm}$ & 0,525 & $492 \mathrm{ppm}$ \\
& $800 \mathrm{ppm}$ & 0,510 & \\
& $1000 \mathrm{ppm}$ & 0,457 & \\
\hline
\end{tabular}

\section{KESIMPULAN}

Pada penelitian ini terbukti bahwa senyawa metabolit sekunder yang dihasilkan oleh bakteri endofit daun kelor tidak sama seperti inangnya dan ekstrak supernatan bakteri endofit memiliki aktivitas antioksidan yang lemah dengan nilai $\mathrm{IC}_{50}$ sebesar 492 ppm.

Diperlukan penelitian lebih lanjut untuk mengisolasikan bakteri endofit pada tanaman kelor dari berbagai bagian tanaman seperti batang dan akar dimana lokasi tumbuh dari tanaman sedapatnya berasal dari berbagai lokasi yang berbeda.

\section{DAFTAR PUSTAKA}

1. Amir, H , Bambang Gonggo Murcitro, AS Ahmad, Murni Nur Islamiah Kassim ,The Potential Use Of Phaleria macrocarpa Leaves Extract As An Alternative Drug For Breast Cancer Among Women Living In Poverty, Asian Journal For Poverty Studies (AJPS), 2017, 3(2):138-145.

2. Pangestu, N.S, Nurhamidah, Elvinawati, Aktivitas Antioksidan dan Antibakteri Ekstrak Daun Jatropha gossypifolia L, Alotrop, 2017:1(1):15-19. 
3. Amir, H, Bambang Gonggo Murrcitro, , Uji Microtetrazolium (MTT) Ekstrak Metanol Daun Phaleriamacrocarpa (Scheff.) Boerl Terhadap Sel Kanker Payudara $\mathrm{MCF}_{7}$, Alotrop, 2017:1(1):27-32.

4. Sarfina, J, Nurhamidah, Dewi Handayani., 2017, Uji Aktivitas Antioksidan Dan Antibakteri Ekstrak Daun Ricinuscommunis L (Jarak Kepyar), Alotrop, 2017:1(1):66-70.

5. Anwar, F, Latif, S, Asraf, M, Gilani, A,H, Moringa oleifera: A food Plant with Multiple Medicinal Uses, Phytother.Res, 2007:21:17-25.

6. Putra , I.W.D.P., Anak Agung Gde Oka Dharmayudha, Luh Made Sudimartini, Identifikasi Senyawa Kimia Ekstrak Etanol Daun Kelor (Moringa oleifera L) di Bali, Indonesia Medicus Veterinus , 2016 :5(5) : 464-473.

7. Ramadenti. F, Agus Sundaryono., Dewi Handayani, . Uji Fraksi Etil Asetat Daun Sungkai Terhadap Plasmodium Berghei Pada Mus Musculus. Alotrop, 2017:1(2): 94-97.

8. Hasanah, U., Yusriadi , Akhmad Khumaidi Formulasi Gel Ekstrak Etanol Daun Kelor (Moringa oleifera Lam) Sebagai Antioksidan, Online Journal of Natural Science, 2017:6(1) :46-57.

9. Toripah, S.S., Jemmy Abidjulu, Frenly Wehantouw., Aktivitas Antioksidan Dan Kandungan Total Fenolik Ekstrak Daun Kelor (Moringa Oleifera Lam), Pharmacon : Jurnal Ilmiah Farmasi - Unsrat, 2014 :3 (4):37-43.

10. Lestaridewi , N.K., Mohammad Jamhari , Isnainar, Kajian Pemanfaatan Tanaman Sebagai Obat Tradisional Di Desa Tolai Kecamatan Torue Kabupaten Parigi Moutong, e-JIP Biol , 2017:5(2):92-108.

11. Anwar, F., Said, L., Ashraf, M., Gilani, A.H., 2007, Moringa oleifera: a Food Plant with Multiple Medicinal Uses, Phytotherapy Research, 21:17-25.

12 Mohamad, H., Y. Andriani., K. Bakar., C.C.Siang.,D.F. Syamsumir.,A.Alias, Effect of drying method on anti -microbial, anti-oxidant activities and isolation of bioactive compounds from Peperomia pellucida (L) Hbk. Journal of Chemical and Pharmaceutical Research , 2015:7(8): 578-584.
13. Andriani, Y, Leni Marlina , Habsah Mohamad, Hermansyah Amir, Siti Aisha M Radzi , Jasnizat Saidin , Anti -Inflammantory Activity Of Bacteria Associated With Marine Sponge (Haliclona Amboinensis) Via Reducting No Production And Inhibiting Cyclooxygenase1-Cyclooxygenase-2, And Secretory Phospholipase A2 Activities, Asian J Pharm Clin Res, 2017: 10(11):95-100.

14. Radji, M., Peranan Bioteknologi dalam Mikroba Endofit dalam Pengembangan Obat Herbal. Majalah Ilmu Kefarmasian. 2005: 2(3): 133-136.

15. Tanaka, M., Harmastini, S., Miho, T., Katsuichi, S., Manabu, S., Titik, K.p., Made, S.P., Fusao,T., Isolation, Screening, and phylogenetic identification of Endophytes from Plants in Hokkaido Japan and Java Indonesia. Journal Microbes and Environments, 1999:14(4) 237-241.

16. Shirly,K., Shanny, F, Wahyudi, P , Uji Aktivitas Antimikroba Metabolit Bioaktif Mikroba Endofitik TanamanTrengguli (Cassiafistula L.). JurnalFarmasi Indonesia, 2006: 3(2): 97-102.

17. Radzi, S.A.M., Y. Andriani, H. Mohamad, T.S.T. Muhammad, and J. Saidin. In-vitro anti-inflammatory activities of extracts from bacteria associated with marine sponges:Theonella SP. Jurnal Teknologi (Sciences \& Engineering), 2015:77(25): 165-169.

18. Widowati, T.Bustanussalam, Harmastini, S., Partomuan, S., Isolasi dan Identifikasi Kapang endofit dari Tanaman Kunyit (Curcuma longa L.) sebagai Penghasil Antioksidan, Biopropal Industri, 2016:7, (1):9-16.

19. Desriani., Ukhradia, M.S., Maria, B., Akhmad, R., Puspita, L., Isolasi dan Karakterisasi Bakteri Endofit dari Daun Binahong dan Ketepeng Cina. Jurnal Kesehatan Andalas. 2014: 3(2):89-93.

20. Strobel, G.A., Daisy, B., Biorespecting for Microbial Endophytes and Their Natural Products,Microbial Molecular Biology Review, 2003: 67 :491-502.

21. Suriaman, E., Solikhatul Khasanah, Skrining Aktivitas Antibakteri Daun Kelor (Moringa oleifera), Daun Bidara Laut (Strychnos ligustrina Blume), Dan 
Amoxicilin Terhadap Bakteri Patogen Staphylococcus aureus, Jurnal Biota, 2017 : 3(1):21-25.

22. Kuntari, Z, Sumpono, Nurhamidah , Aktivitas Antioksidan Metabolit Sekunder Bakteri Endofit Akar Tanaman Moringa oleiferaL (Kelor) .Alotrop, 2017:1(2):8084.

23. Molyneux, P. , The Use of the Stable Free Radical diphenylpicrylhydrazyl (DPPH) for Estimating Antioxidant Activity, Journal Songklanakarin J. Sci. Technol, 2004 : 26 (2): 211-219.

24. Abdullah, W., Max Revolta J. Runtuwene , Vanda Selvana Kamu, Uji Fitokimia Dan Penentuan Inhibition Concentration 50\% Pada Beberapa Tumbuhan Obat di Pulau Tidore, Jurnal Ilmiah Sains, 2014 :14(2) : 95-99.

25. Andriani, Y, Habsah Mohamad, M.N.I, Kassim., N.D. Rosnan., D.F. Syamsumir., J.Saidin, Evaluation on Hydnophytum formicarum Tuber from Setiu Wetland (Malaysia) and Muara Rupit ( Indonesia) for Antibacterial and Antioxidant activities and anti-cancer Potency against MCF-7 and HeLa Cell. Journal of Applied Pharmaceutical Science, 2017:7(9):30-37.

26. Triana, O., Purbowatiningrum Ria Sarjono ,Nies Suci Mulyani , Isolasi Bakteri Endofit pada Rimpang Jahe Merah (Zingiber officinale Linn. Var Rubrum) Penghasil Senyawa Antioksidan, Jurnal Kimia Sains dan Aplikasi , 2017 :20(1) : 25 - 29.

27. Al Banna, M.Z., Hartati, Isolasi dan Uji Antagonistik Bakteri Endofit dan Rizosfer Bambu Asal Tana Toraja Terhadap Jamur Patogen Tanaman, Jurnal Dinamika, 2017 : 8(2):20-30.

28. Lestari, D.M., Nurul Mahmudati , Sukarsono, Nurwidodo1, Husamah, Aktivitas Antioksidan Ekstrak Fenol Daun Gayam (Inocarpus fagiferus Fosb), Biosfera, 2018:35(1):37 - 43.

29. Hanani, E., Abdul Mun'im, Ryany Sekarin, Identifikasi Senyawa Antioksidan Dalam
Spons Callyspongia SP Dari Kepulauan Seribu, Majalah Ilmu Kefarmasian, 2005 : 2(3):127-133.

30. Mulangsri, D.A.K., Aqnes Budiarti, Endah Novia Saputri, Aktivitas Antioksidan Fraksi Dietileter Buah Mangga Arumanis ( $\mathrm{Ma}$ ngifera indica L.) dengan Metode DPPH, Jurnal Pharmascience, 2017:4(1):85 - 93.

31. Rizkayanti, Anang Wahid. M. Diah, Minarni Rama Jura, Uji Aktivitas Antioksidan Ekstrak Air Dan Ekstrak Etanol Daun Kelor (Moringa Oleifera Lam ), J. Akad. Kim, 2017 : 6(2): 125-131.

32. Susilowati, Suharyanto., Potensi Antioksidan dan Kadar Fenolik Total Fraksi Air dan Fraksi Etil Asetat Daun Kelor (Moringa oleifera Lam.), Jurnal Permata Indonesia , 2017:8(2):26- 38.

33. Musa ,N. S, Nadia Madiha Ramli, Jaznizat Saidin,Yosie Andriani, Antioxidant And Cytotoxicity Propertise of Ethyl Acetate Fractions Of Pandanus tectorius Fruit Against HELA Cell Line, Alotrop, 2017: 1(2):106-112.

Penulisan Sitasi Artikel ini ialah

Yati, S.J., Sumpono, I Nyoman Candra., Potensi Aktivitas Antioksidan Metabolit Sekunder Dari Bakteri Endofit Pada Daun Moringa oleifera L, Alotrop, 2018:2(1):82-87. 